\title{
Unpacking the 'green' recovery spending: an assessment of likely implications on greenhouse gas emissions towards 2030 for key emitters
}

Frederic Hans ( $\nabla$ f.hans@newclimate.org )

NewClimate Institute, Cologne, Germany https://orcid.org/0000-0001-6266-9859

\section{Santiago Woollands}

NewClimate Institute, Cologne, Germany \& Willy Brandt School of Public Policy, University of Erfurt, Germany

\section{Leonardo Nascimento}

NewClimate Institute, Cologne, Germany \& Environmental Systems Analysis Group, Wageningen University, The Netherlands https://orcid.org/0000-0003-4133-4624

\section{Niklas Höhne}

NewClimate Institute, Cologne, Germany \& Environmental Systems Analysis Group, Wageningen University, The Netherlands https://orcid.org/0000-0001-9246-8759

Takeshi Kuramochi ( $\nabla$ t.kuramochi@newclimate.org )

NewClimate Institute, Cologne, Germany \& Copernicus Institute of Sustainable Development, Utrecht University, The Netherlands https://orcid.org/0000-0002-3976-0133

\section{Research Article}

Keywords: Green recovery, Fiscal stimulus, COVID-19, climate change mitigation

Posted Date: October 28th, 2021

DOI: https://doi.org/10.21203/rs.3.rs-1024400/v1

License: (c) (i) This work is licensed under a Creative Commons Attribution 4.0 International License. Read Full License

Version of Record: A version of this preprint was published at Climate Action on March 7th, 2022. See the published version at https://doi.org/10.1007/s44168-022-00002-9. 


\title{
Unpacking the 'green' recovery spending: an assessment of likely implications on greenhouse gas emissions towards 2030 for key emitters
}

\author{
Frederic Hans ${ }^{1 *}$, Santiago Woollands ${ }^{1,2}$, Leonardo Nascimento ${ }^{1,3}$, Niklas Höhne ${ }^{1,3}$, \\ Takeshi Kuramochi ${ }^{1,4 *}$ \\ ${ }^{1}$ : NewClimate Institute, Cologne, Germany \\ 2: Willy Brandt School of Public Policy, University of Erfurt, Germany \\ 3: Environmental Systems Analysis Group, Wageningen University, The Netherlands \\ 4: Copernicus Institute of Sustainable Development, Utrecht University, The Netherlands \\ *Corresponding authors: Frederic Hans (f.hans@newclimate.org), Takeshi Kuramochi \\ (t.kuramochi@newclimate.org)
}

\section{Abstract (current: 200 words)}

This paper analyses how fiscal stimulus spending in response to the COVID-19 pandemic supports the low-carbon transition. We developed a new framework to categorize rescue and recovery spending measures according to their level of greenness and their type of expected impact on greenhouse gas emissions. This framework allows to better capture how measures' emission impacts may unfold over time and to identify the share of fiscal spending missing robust conditions or incentives to be considered low-carbon. We assess nearly 2,500 measures announced by 26 emitters as of May 2021, representing around 65\% of global GHG emissions in 2018. Our findings show that the largest share (35\%) of spending with potential GHG emission implications went to measures that supported the status quo in the respective countries when there were low-carbon alternatives. Our assessment reveals the different magnitudes to which the emitters have missed the opportunity for a green recovery. While low-carbon spending is also significative in size (22\%) across countries, almost two-thirds of it can be considered enabling or catalytic in nature and will rather unfold its impact over time. This fiscal spending will trigger transformational change over time but will not necessarily lead to direct emission reduction impacts before 2030 .

Keywords: Green recovery, Fiscal stimulus, COVID-19, climate change mitigation 
Governments' existing greenhouse gas (GHG) emissions reduction targets up to 2030 (Nationally Determined Contributions: NDCs) collectively remain unambiguously inadequate to put the world on an emissions pathway aligned with the Paris Agreement's 'well below $2^{\circ} \mathrm{C}$ ' and $1.5^{\circ} \mathrm{C}$ temperature limit (UNEP, 2020). The Paris Agreement requests countries to update their NDCs every five years, with the first update round in 2020 (UNFCCC, 2015, Art. 4.9). Countries have been expected to strengthen their GHG emissions reduction targets significantly in the 2020 update to keep the temperature goals of the Paris Agreement within reach (Höhne, den Elzen, et al., 2020).

The fiscal rescue and recovery spending in response to the COVID-19 pandemic coincided with the first NDC update round. Lack of progress in the last decade has enlarged the challenge (Höhne, den Elzen, et al., 2020), while the mandatory accelerated transition towards a global low-carbon economy requires full alignment of all fiscal spending with the Paris Agreement goals. The Paris Agreement requires Parties to make "make finance flows consistent with a pathway towards low greenhouse gas emissions and climate-resilient development" to achieve the Paris temperature goals (UNFCCC, 2015, Art. 2.1c and 2.1a).

Since the beginning of the COVID-19 pandemic, many governments worldwide have pledged to steer their rescue and recovery spending towards a 'green' recovery (Petersberg Climate Dialogue XI, 2020), often citing numerous economic, social, and environmental benefits of low-carbon spending (Höhne, Hans, et al., 2020). As a response, since March 2020, an increasing body of literature have studied rescue and recovery spending by these national governments to assess countries' actions "on the ground" in light of their pledges and evaluate the overall direction of the rescue and recovery efforts in terms of their climate change mitigation effects.

A first strand of literature conducts a variety of ex-ante assessments of different fiscal spending possibilities (Hepburn et al., 2020; IEA, 2020; Jotzo et al., 2020; Krebel et al., 2020). They aim to identify synergies between different economic, social, and environmental priorities by national governments. This strand of literature provides theoretical performance assessments of different policies against pre-defined criteria. Where country specific circumstances have been analysed, the assessments also provided recommendations on what to spend on and how much.

A second strand of research examines different scenarios using stylised assumptions on the pandemic's duration and intensity, and a hypothetically assumed carbon intensity of governments' fiscal responses (Buckle et al., 2020; Climate Action Tracker, 2020; Forster et al., 2020; IEA, 2020; Lahcen et al., 2020; Meles et al., 2020; Pollitt et al., 2020; Shan et al., 2021). Based on assumptions about the possible 'shapes' of economic recovery, these studies estimate the time it will take for the world (or selected economies) to recover or surpass pre-pandemic GDP levels and how different compositions of rescue and recovery packages can influence the recovery's speed and carbon intensity. Most studies provide individual estimates of GDP and greenhouse gas (GHG) emissions growth under stylized assumptions of 'traditional stimulus' and 'green stimulus' over different timeframes, ranging from 2024 (Shan et al., 2021) to 2050 (Forster et al., 2020).

A third strand tracks and assesses incoming rescue and recovery packages by national governments worldwide. These trackers assess the greenness of rescue and recovery measures across different countries (E3G \& Wuppertal Institut, 2021; Energy Policy Tracker, 2021; IEA, 2021c; O'Callaghan, Yau, Murdock, Tritsch, Janz, Blackwood, Purroy Sanchez, L., Sadler, et al., 2021; OECD, 2021; Vivid 
Economics, 2021). They often have different scopes in terms of country coverage, measure coverage, and method to differentiate between low-carbon and high-carbon measures. These applied frameworks generally classify policy archetypes into different groups based on their expected contribution to mitigation outcomes, and in some cases include other socio-economic considerations such as short and long-run multipliers, impacts on air pollution, and others. None of the trackers systematically identifies measures that could have become low-carbon in nature if governments would have implemented robust low-carbon conditions or incentives alongside them. Such identification of measures supporting the status quo would allow for a more nuanced assessment of a missed opportunity for a green recovery by key emitters.

The third strand of literature provides insights into the size and spending patterns of rescue and recovery packages but have only provided limited assessment on the spending's implications on GHG emissions over time. For example, the Oxford Global Recovery Observatory classifies fiscal measure archetypes according to their short-term and long-term emissions impacts (O'Callaghan, 2021). The assessment of rescue and recovery packages of the 50 largest economies shows that only a few countries such as France or South Korea have a positive net impact in reducing GHG emissions (O'Callaghan, Yau, Murdock, Tritsch, Janz, Blackwood, Purroy Sanchez, L. Sadler, et al., 2021). A deeper assessment of how these measures differ in terms of their contribution to emission reductions (or increases) over time remains outside of their scope.

Against this backdrop, this study contributes to existing literature by providing a new methodological framework and subsequent analysis guided by the following research question: How does fiscal rescue and recovery spending in response to the COVID-19 pandemic differ in terms of its likely implications on GHG emissions over time? We analyse 16 Member States of the European Union (EU) ${ }^{1}$ and 10 other selected key emitters (Brazil, China, India, Indonesia, Japan, Saudi Arabia, South Africa, South Korea, the United Kingdom (UK), and the United States of America (USA)). These countries together accounted for around 65\% of global GHG emissions in 2018 (EDGAR, 2019).

This article is structured as follows. Section 0 describes the methods and data used for the analysis. We introduce a novel framework to categorise emission impact type of COVID-19 rescue and recovery measures to complement the level of greenness categorisation used in the literature. We then apply this framework to a harmonised dataset of almost 2,500 rescue and recovery measures in the period between January 2020 and May 2021. Section 3 presents and discusses the findings of the analyses on the composition of fiscal rescue and recovery spending in response to the COVID-19 pandemic for according to this framework. Finally, conclusions and policy recommendations are drawn in Section 4. 
2.1 Categorisation of fiscal rescue and recovery measures by level of greenness and emission impact type

\subsubsection{Framework}

In their analysis of stimulus spending after the financial crisis of 2009/2010, Strand and Toman (2010) argued that the categorization of spending measures into high-carbon and low-carbon measures lacks precision to identify differences in the way that each type of spending measure affects GHG emissions over time. A more nuanced framework to assess the expected emissions impact of stimulus spending thus can enhance the understanding of how rescue and recovery ultimately affect countries emissions trajectories.

For this purpose, we introduce an emissions impact type categorisation to assess the expected impact of fiscal rescue and recovery measures on GHG emissions in the period towards 2030 (Figure 1). The proposed impact type categorisation differentiates between 'direct' measures, 'enabling' measures, and 'catalytic' measures. This differentiation is inspired by other existing assessment frameworks. For example, the EU Taxonomy Regulation (TEG, 2020) classifies economic activities with substantial contributions to climate change mitigation targets either based on their own performance or by enabling other activities to provide substantial contributions. ${ }^{2}$

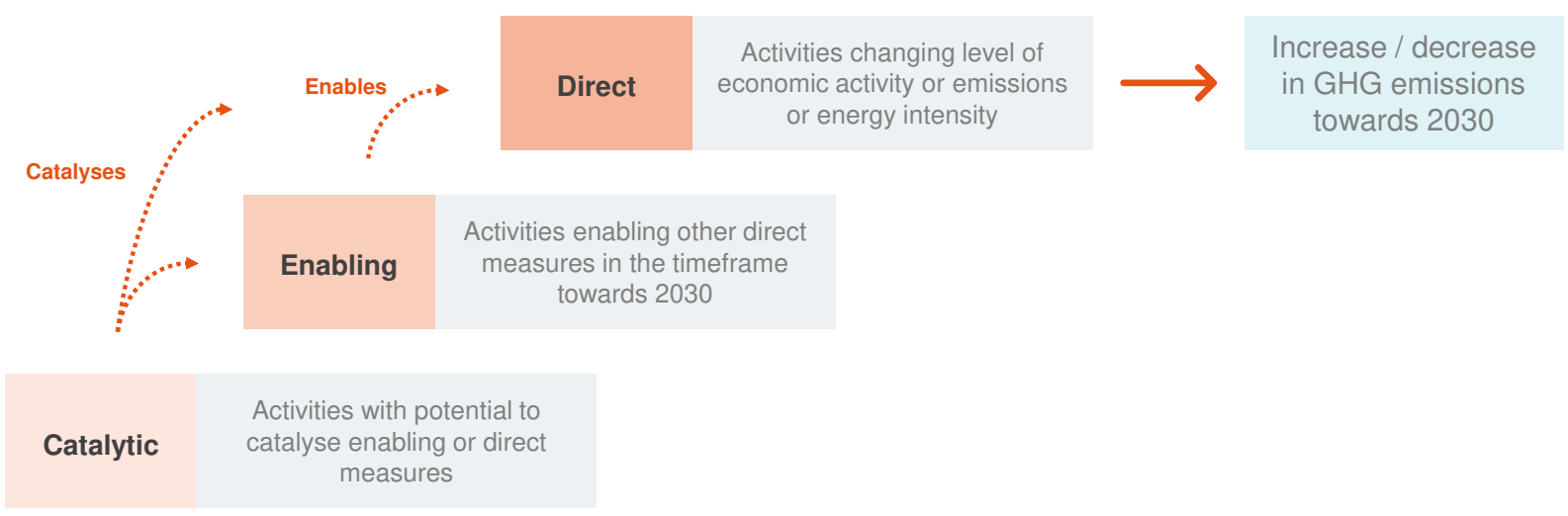

Figure 1: Conceptual differentiation between direct, enabling, and catalytic measures. Source: authors.

We complement the emissions impact type categorisation with the level of greenness categorisation previously used in Höhne et al. (2020). The framework categorises rescue and recovery measure as (1) low-carbon, (2) high-carbon, (3) unclear, and (4) neutral (see S1 in the Supplementary Online Material (SOM) for definitions).

Our study further introduces an additional 'supporting the status quo' category. This category comprises measures that cannot be explicitly coded as high-carbon or low-carbon but substantiate current businessas-usual practice (e.g., corporate airline bailouts without conditions for net zero transition). Such measures would have presented an opportunity for policy makers to implement accompanying distinct

\footnotetext{
${ }^{2}$ Within our definition of 'direct' emissions impact measures, we include measures that support activities considered to contribute based on their own performance (i.e., those associated with sequestration or very low or zero emissions) and those considered in the taxonomy as transitional activities (i.e., those activities considered necessary in a zero-carbon economy, but which are not currently close to a zero-carbon level).
} 
conditions for a low-carbon transition coupled to the respective fiscal rescue and recovery spending item.

The level of greenness for each 'supporting the status quo' measure highly depends on the emissions intensity of current practice in the respective country and sector. This measure category therefore differs from most of the low-carbon and high-carbon measure archetypes (e.g., a coal-power plant would always be coded high-carbon). It remains outside the scope of this analysis to further differentiate 'supporting the status quo' category according country-specific baselines as some other studies in existing literature have done (Vivid Economics, 2021).

Figure 2 combines the emissions impact type and level of greenness into one framework, complemented by hypothetical examples for illustration.

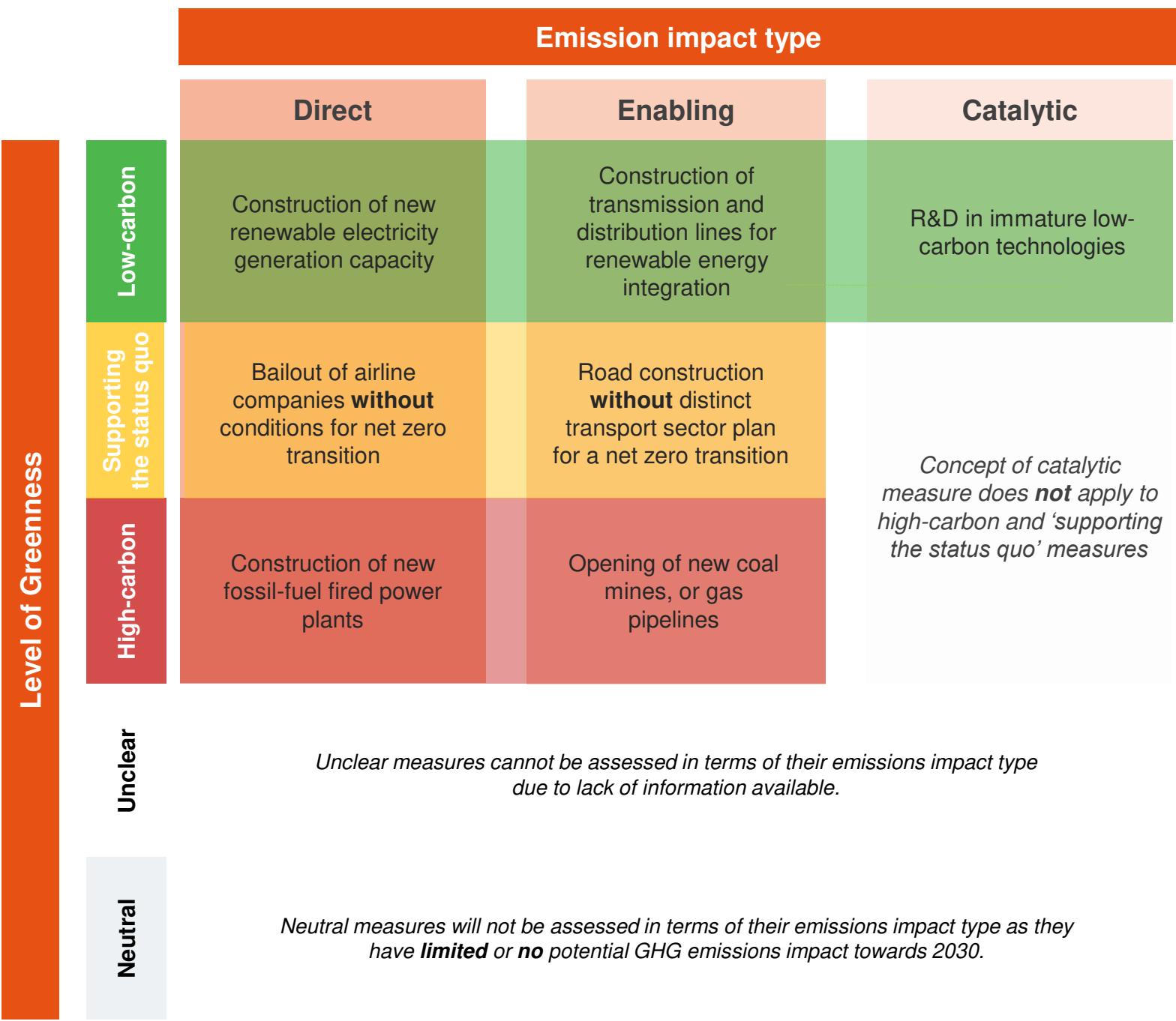

Figure 2: Framework to assess fiscal rescue and recovery measures according to their emissions impact type greenhouse gas emissions (GHG) towards 2030 (direct, enabling, catalytic) and their level of greenness (lowcarbon, supporting status quo, high-carbon, unclear, neutral).

\section{Direct emissions impact measures}

We define measures as 'direct' if their implementation changes the level of economic activity and/or emissions or energy intensity in the timeframe towards 2030. A 'direct' measure's own performance impact GHG emissions levels towards 2030. Measures that support transitional activities (for example measures that support 'champion' sectors or aim to boost export industries) will only be considered as 
'low-carbon' if they unambiguously support energy or emissions efficiency improvements (TEG, 2020). Our assessment of 'direct' emissions impact measures also incorporates those that support 'high-carbon' activities, understood as those that undermine long-term environmental goals by contributing to higher GHG emissions and lead to lock-in of high carbon infrastructure.

\section{Enabling measures with no (or limited) own direct impact}

We define measures as 'enabling' if their realisation enables the implementation of other activities with direct emissions impact in the timeframe towards 2030. An enabling measure's own performance has no or only limited direct emission impact itself. 'Enabling' measures would further need to meet Do No Significant Harm (DNSH) conditions to qualify as low-carbon measures. This follows the EU Taxonomy Regulation (TEG, 2020) that stipulates that measures should (1) not lead to lock-in of assets that undermine environmental goals and (2), have a substantial positive environmental impact based on life-cycle considerations. No such DNSH conditions exist for 'enabling' measures that qualify as highcarbon measures.

\section{Catalytic measures with no (or limited) own direct impact}

We define measures as 'catalytic' if their implementation in the timeframe towards 2030 holds the potential to allow new direct or enabling measures to be implemented after 2030. Such catalytic measures are characterized by uncertainty to which extent direct or enabling measures will be realised in the longer term. Catalytic measures only apply for low-carbon activities since high-carbon activities are generally based on mature technologies and well-established practices. Fiscal spending such as R\&D can make such high-carbon technologies more efficient (e.g., highly efficient coal technology or internal combustion engines) but would not qualify as catalysing new technologies.

The role of innovation to achieve global environmental targets and provide significant economic benefits in terms of economic growth and employment is widely acknowledged (Aghion et al., 2014; O'Callaghan \& Murdock, 2021). Catalytic measures such as spending in research and development (R\&D), demonstration projects, and other measures that support innovation in uncertain, yet potentially promising low-carbon technologies are characterized by their (high) uncertainty to lead to successful outcomes and their (high) potential impact to further develop emerging and immature technologies. Catalytic measures can support activities with direct or enabling impact while showing substantial time lags between investment and output (O’Callaghan \& Murdock, 2021).

\subsubsection{Data collection and harmonisation}

Our analysis primarily relies on data from the Global Recovery Observatory database as the most comprehensive fiscal rescue and recovery spending database for all key emitters except the $16 \mathrm{EU}$ Member States (O'Callaghan, Yau, Murdock, Tritsch, Janz, Blackwood, Purroy Sanchez, L., Sadler, et al., 2021). Data from the Energy Policy Tracker fills identified data gaps for India, Japan, Indonesia, Saudi Arabia, South Africa and Brazil (Energy Policy Tracker, 2021). 
Table 1: Overview of fiscal rescue and recovery spending databases used for this study's data collection

\begin{tabular}{|c|c|c|c|c|c|c|}
\hline \multirow{3}{*}{$\begin{array}{l}\text { Tracker } \\
\text { (Last update) }\end{array}$} & \multirow{3}{*}{$\begin{array}{l}\text { Country } \\
\text { coverage }\end{array}$} & \multicolumn{3}{|c|}{ Coverage of measures } & \multicolumn{2}{|c|}{ Evaluation framework } \\
\hline & & \multicolumn{2}{|c|}{ Fiscal measures } & \multirow{2}{*}{$\begin{array}{c}\text { Regulatory } \\
\text { measures }\end{array}$} & \multirow{2}{*}{ Level of greenness } & \multirow{2}{*}{ Emissions impact type } \\
\hline & & Rescue & Recovery & & & \\
\hline $\begin{array}{l}\text { Global Recovery } \\
\text { Observatory } \\
(\mathbf{2 8 . 0 5 . 2 0 2 1 )}\end{array}$ & $\begin{array}{l}50 \text { largest } \\
\text { economies }\end{array}$ & Yes & Yes & No & $\begin{array}{l}\text { 5-point Likert scale } \\
\text { per policy (sub- } \\
\text { )archetype used to } \\
\text { categorise measures } \\
\text { across countries: }-2 \text { to } \\
+2\end{array}$ & $\begin{array}{l}\text { 5-point Likert scale per } \\
\text { policy archetype used to } \\
\text { categorise measures } \\
\text { across countries on } \\
\text { short-term GHG impact, } \\
\text { long-term GHG impact, } \\
\text { and net GHG impact }\end{array}$ \\
\hline $\begin{array}{l}\text { Energy Policy } \\
\text { Tracker } \\
(\mathbf{0 1 . 0 6 . 2 0 2 1 )}\end{array}$ & $\begin{array}{l}\text { G20 plus } 11 \\
\text { additional } \\
\text { countries }\end{array}$ & Yes & Yes & Yes & $\begin{array}{l}\text { Coding of single } \\
\text { measures as } \\
\text { conditional or } \\
\text { unconditional support } \\
\text { for energy types: (1) } \\
\text { Fossil (2) Clean, (3) } \\
\text { Other }\end{array}$ & Not available \\
\hline $\begin{array}{l}\text { Green Recovery } \\
\text { Tracker } \\
(\mathbf{0 1 . 0 6 . 2 0 2 1 )}\end{array}$ & $\begin{array}{l}16 \text { EU Member } \\
\text { States }\end{array}$ & No & Yes & No & $\begin{array}{l}\text { Coding of single } \\
\text { measures on a 6-point } \\
\text { Likert scale to assess } \\
\text { level of contribution to } \\
\text { the green transition: } \\
\text { (1) Neutral, (2) } \\
\text { Unclear, (3) Very } \\
\text { Negative, (4) } \\
\text { Negative, (5) Positive, } \\
\text { (6) Very Positive }\end{array}$ & Not available \\
\hline This study & $\begin{array}{l}10 \text { key emitters } \\
\text { plus } 16 \mathrm{EU} \\
\text { Member States }\end{array}$ & Yes & Yes & Partially & $\begin{array}{l}\text { Coding per policy } \\
\text { (sub-)archetype used } \\
\text { to categorise measures } \\
\text { across countries: (1) } \\
\text { High-carbon, (2) } \\
\text { Supporting status quo, } \\
\text { (3) Low-carbon, (4) } \\
\text { Unclear, (5) Neutral }\end{array}$ & $\begin{array}{l}\text { Coding per policy (sub- } \\
\text { )archetype used to } \\
\text { categorise measures } \\
\text { across countries: (1) } \\
\text { Direct, (2) Enabling, and } \\
\text { (3) Catalytic }\end{array}$ \\
\hline
\end{tabular}

Data for the 16 EU Member States comes from the Green Recovery Tracker database (E3G \& Wuppertal Institut, 2021), including domestically and EU-funded fiscal rescue and recovery measures. ${ }^{3}$ This dataset, however, excludes tracking of any liquidity support provided to corporations and other rescue measures, focusing entirely on recovery spending. For this reason, a direct comparison of $16 \mathrm{EU}$ Member States assessed in this analysis against other key emitters faces certain limitations.

We coded all rescue and recovery measures from the three datasets using the Global Recovery Observatory's archetype list (O'Callaghan, 2021) and systematically checked all data entries to match the assigned archetype (total of 2,472 measures). The list has been extended to include the level of greenness and emissions impact type of our framework introduced in Section 0 (see full archetype list in Table S1 of the SOM).

\footnotetext{
${ }^{3}$ Our analysis assesses the full scope of rescue and recovery spending in the 16 EU Member States. This should not be confused with the sub-part of their spending from the EU Recovery and Resilience Facility (RRF), which imposes a minimum of 37\% to be spent on climate change and applies a 'do-no-significant-harm' principle to all EU RRF funding.
} 
The first step in the coding process was to take the mentioned archetype list of possible fiscal stimulus spending measures and assign a level of greenness and emissions impact type code to each archetype. In a second step, we applied this code to the Global Recovery Observatory's dataset which already included a categorization of measures according to their own typology. We then applied this typology to measures from the Green Recovery Tracker and the Energy Policy Tracker and cross-checked the data for each country to avoid double counting between different trackers (where applicable). Measures for which we identified likely double counting but could not confirmed due to lack of precise information were excluded from the count. In a last step, we performed a systematic review of individual measures to check for coding misfits, i.e. measures for which our initial coding per policy archetype does not properly fit the individual measure. S2 of the SOM provides further information on the data collection, data harmonization, and data coding.

\section{Results and discussion}

The ten selected key emitters and 16 Member States of the European Union (16 EU MS thereafter) jointly commit to a total of around USD 11.1 trillion in fiscal rescue and recovery spending as of May 2021 (Figure 3). Of this, we identify around USD 3 trillion as fiscal spending with potential GHG emissions impacts for further analysis on its likely emissions impact. The other USD 8.1 trillion represent 'neutral' fiscal spending that no potential GHG emissions impact towards 2030 in line with our framework introduced in Section 2.1.1.

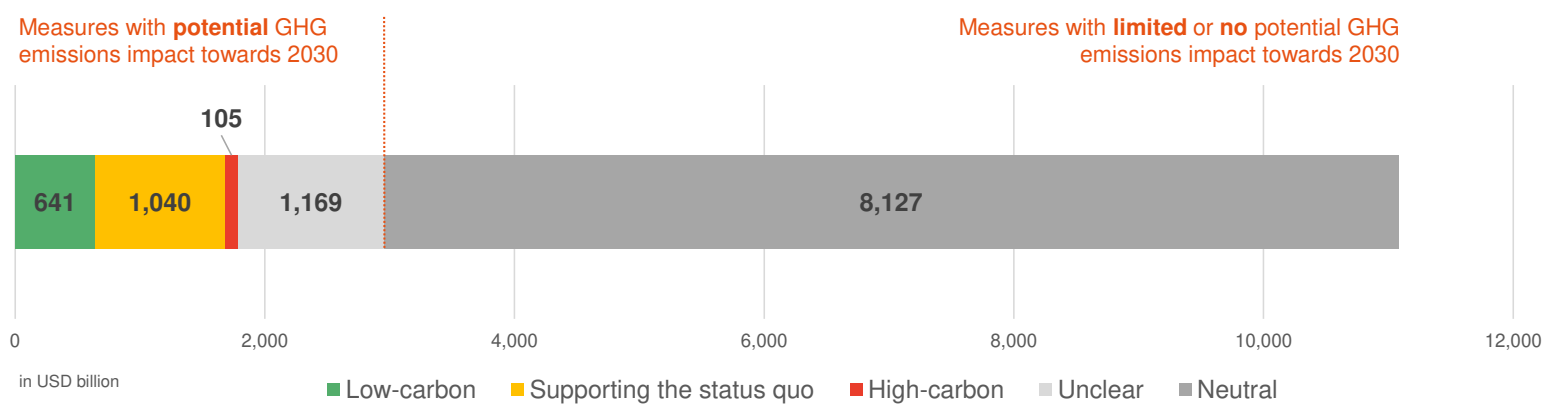

Figure 3: Overview of aggregated fiscal rescue and recovery spending for $10 \mathrm{key}$ emitting countries and 16 Member States of the European Union assessed in the present analysis as of May 2021. Source: Data from Global Recovery Observatory (2021) and Energy Policy Tracker (2021) for ten key emitters and Green Recovery Tracker (2021) for 16 EU Member States with authors' own coding of all individual measures inspired by measure archetype of the Global Recovery Observatory (O'Callaghan, 2021).

\subsection{Level of greenness across key emitters' fiscal spending}

Most countries dedicate fiscal rescue and recovery spending to measures considered 'supporting the status quo' to further accelerate climate action (Figure 4), representing an average of $35 \%$ across all countries and up to $73 \%$ of fiscal spending for single countries. This spending includes a wide range of measures such as liquidity support for large corporations or general value added tax (VAT) reductions without any conditions for a net zero transition.

Large shares of fiscal rescue and recovery spending further remain 'unclear' given lack of detailed information, totalling to almost USD 1.2 trillion across all countries (40\% of all fiscal spending with potential impact towards 2030). This is especially relevant for large fiscal spenders such as the $16 \mathrm{EU}$ MS, the USA, China, the UK, and India. In the case of China, this is for example driven by lack of 
granularity in China's 2021 Government Work Report announced in March 2021 available to the authors (O’Callaghan, Yau, Murdock, Tritsch, Janz, Blackwood, Purroy Sanchez, L., Sadler, et al., 2021).

The share of low- and high-carbon fiscal spending differs among the key emitters analysed (Figure 4), both in absolute terms and relative to GDP. Low-carbon measures represent around USD 641 billion (22\% of all spending with potential GHG emissions impact towards 2030). This finding is in line with the existing literature; O'Callaghan and Murdock estimated that $18.0 \%$ of all recovery spending of the 50 largest economies could be considered low-carbon (O'Callaghan \& Murdock, 2021); the Green Recovery Tracker estimated that $30 \%$ of spending assessed positive $(16 \%)$ or very positive $(14 \%)$ in Green Recovery Tracker's briefing for 16 EU Member States (Green Recovery Tracker, 2021); only $17 \%$ to $19 \%$ of a total USD 2.25 trillion in announced COVID-19 'recovery' spending ${ }^{1}$ as of May 2021 has gone towards green spending, and only $2.5 \%$ to $12.1 \%$ of total COVID-19 spending has been green or with green co-benefits (O'Callaghan, et al., 2021; OECD, 2021; Vivid Economics, 2021).

The UK, South Korea, Japan, India, and the 16 EU Member States show higher shares of low-carbon spending (30\% or more of all rescue and recovery spending with potential GHG emissions impact). Except for Japan, these countries have also committed the highest total amounts of fiscal rescue and recovery spending. Measures explicitly considered high-carbon amount to USD 105 billion ( 4\% of all spending) across all countries. China and India both spent the highest total amounts on high carbon measures by far, USD 22 billion and USD 52 billion, respectively. India (30\% of its total spending) together with Saudi Arabia (56\%) and Indonesia (27\%) also spent the highest shares of their domestic rescue and recovery spending on high carbon measures.

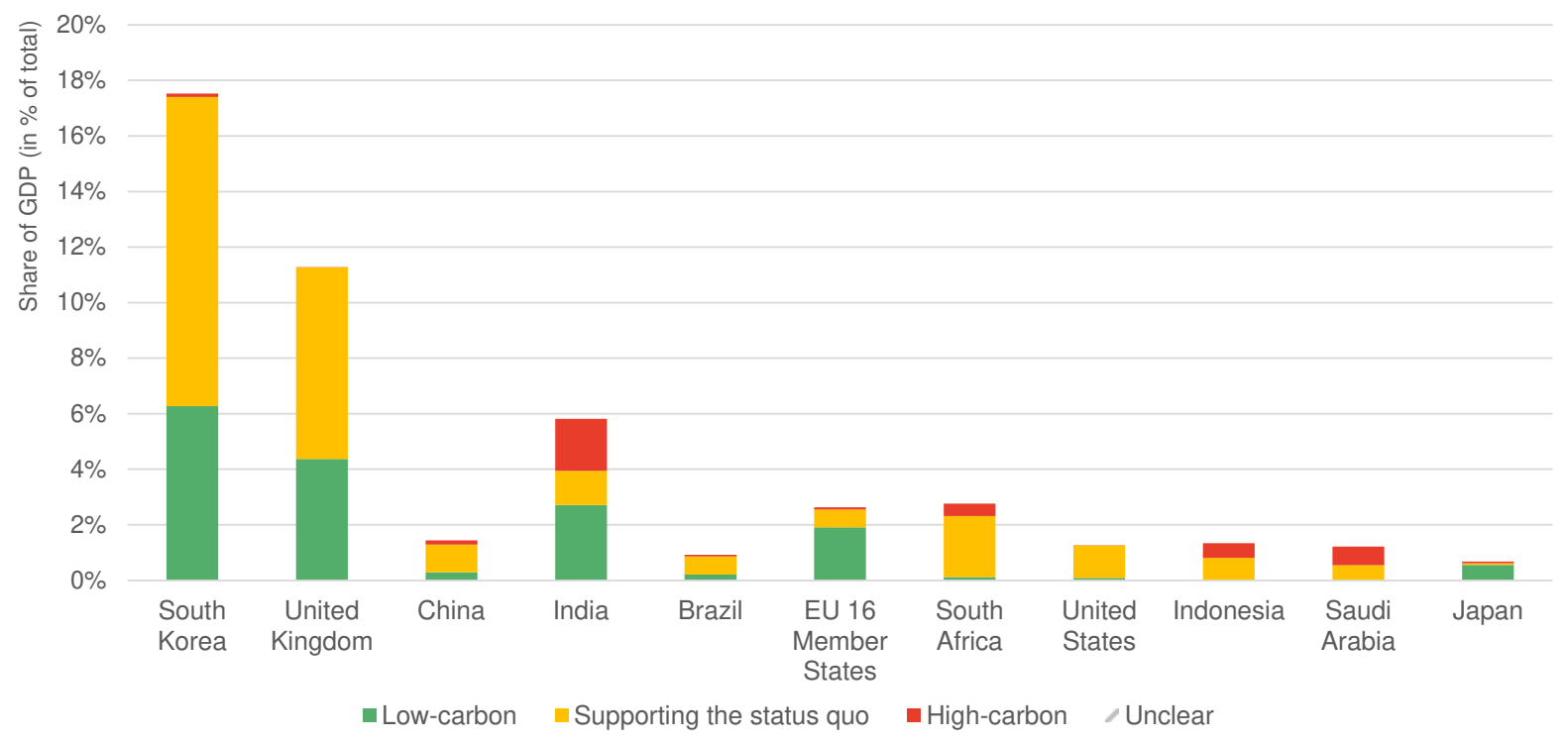

Figure 4: Fiscal rescue and recovery spending as of May 2021 with potential greenhouse gas (GHG) emissions impact per key emitter as a share of GDP.

The summary results across key emitters shows that around 35\% of fiscal spending reinforces a current status quo and have not met the pledges to effectively focus economic rescue and recovery measures on low-carbon activities. South Korea and the United Kingdom dedicate large shares of their rescue and recovery spending to measures supporting the status quo in their economies, representing $11 \%$ and $8 \%$ of their GDP respectively. Such measures comprise, among other, corporate liquidity support for airline companies and other large corporates without specific conditions for a low-carbon transition or VAT reductions without a specific focus on low-carbon products. This suggests that governments might have 
pursued other socio-economic considerations, especially during the initial rescue phase, and showed limited capabilities or willingness to align all emission-relevant fiscal spending with the Paris Agreement's objectives.

On a positive note, explicitly low-carbon spending (22\%) outweighs high-carbon spending roughly five to one. High uncertainty and a lack of available information remains on many rescue and recovery measures given that unclear spending represents around $40 \%$ of all relevant spending with potential GHG emission impact towards 2030.

\subsection{Emissions impact type across key emitters' low-carbon and high-carbon fiscal spending}

The emission impact type categorises fiscal rescue and recovery measures according to their expected likely impact on greenhouse gas emissions (GHG) in the period towards 2030. Error! Reference source not found. Table 2 in the Appendix introduces several examples for rescue and recovery measures considered direct, enabling and catalytic in this study based on the harmonised dataset of almost 2,500 measures. Our analysis across key emitters suggests that most of the low-carbon fiscal spending identified will likely not lead to direct emissions reductions in the short-term as almost two thirds of the low-carbon spending of total USD 641 billion can be considered enabling and catalytic low-carbon measures (Figure 5). The other one-third of all low-carbon spending goes to direct low-carbon measures. Our findings suggest low-carbon fiscal rescue and recovery spending to date will likely unfold its emission reduction impact only over a longer time horizon towards 2030 and beyond. The detailed assessment of the emission impact type of low-carbon and high-carbon measures reveals heterogeneity in spending patterns among key emitters.

In total, all key emitters have spent or announced around USD 230 billion on direct low-carbon measures, representing 36\% of total low-carbon spending (USD 641 billion). Except for China (82\%), USA (53\%), and South Africa (100\%), all countries spend less than 50\% of their total low-carbon spending on direct measures.

Across all key emitters analysed, USD 345 billion have been spent or announced on low-carbon enabling measures, representing around 54\% of total low-carbon spending. Some countries like the United Kingdom, Japan or Brazil dedicate more than $80 \%$ of their low-carbon spending to enabling measures. Other countries such as India, the EU16 and the USA dedicate at least $40 \%$ of their low-carbon spending to enabling measures.

Low-carbon catalytic measures represent $10 \%$ of all low-carbon spending (USD 64 billion). South Korea $(47 \%)$ represents the only country spending more than $10 \%$ of their total low-carbon spending.

Both enabling and catalytic low-carbon measures will play an important role to support the implementation of direct low-carbon measures on a longer time horizon, for example through catalytic $R \& D$ and enabling infrastructure investments but might not immediately lead to the implementation of direct measures itself in the short-run. Substantial further action will be required to effectively reduce emissions globally in the short to medium run towards 2030. 

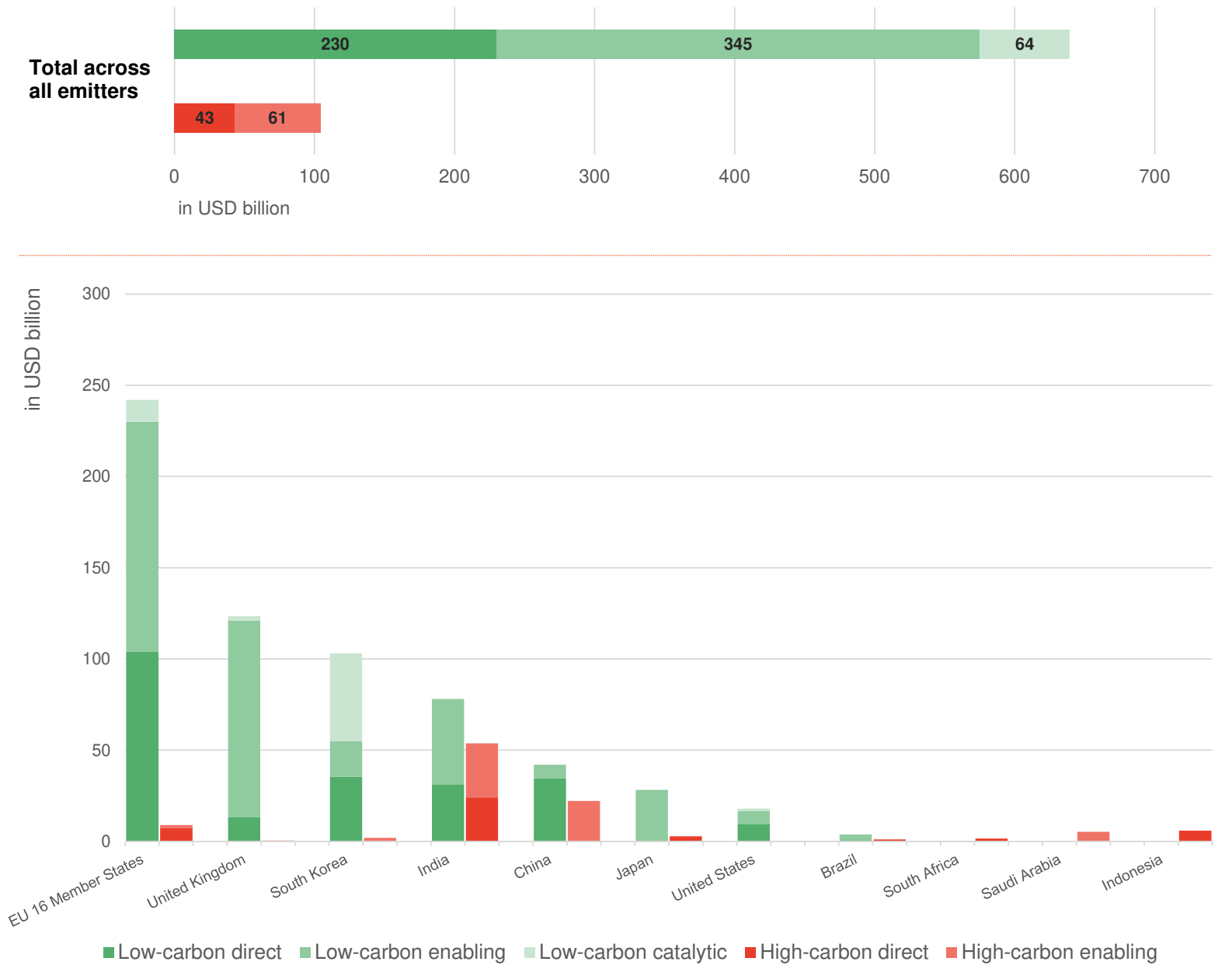

Figure 5: Low-carbon and high-carbon fiscal rescue and recovery spending per key emitter as of May 2021 differentiated by emissions impact type in USD billion.

As for high-carbon spending of USD 104 billion across key emitters, around 42\% of all high-carbon spending can be considered direct in nature, with 58\% representing high-carbon enabling spending.

A total of USD 43 billion has so far been spent or announced in all key emitters analysed for high-carbon direct measures, representing $42 \%$ of all high-carbon spending. Five countries have dedicated all of their high-carbon spending to direct measures, including the United Kingdom, Japan, and Brazil. Other countries such as 16 EUMS (79\%), and India (45\%) have also partially spent on high-carbon direct measures.

High-carbon enabling measures constitute the remaining 58\% (USD 61 billion) of high-carbon spending. The USA (100\%), South Korea (100\%), China (100\%) and Saudi Arabia (96\%) have dedicated all or almost all their high-carbon spending to high-carbon enabling measures. India (55\%), and 16 EU MS (19\%) have also spent partially on high carbon enabling measures, while other countries register no spending on this category.

\subsection{Policy implications of the findlings}

Our analysis based on the publicly available data as of May 2021 suggests that key emitters collectively may have missed the opportunity to use their fiscal rescue and recovery spending to build back their 
economy while fully making good on their responsibility to implement a 'green' recovery aligned with the Paris Agreement goals. The share of low-carbon spending across all key emitters assessed accounts for only $22 \%$ of all spending with potential GHG emissions impact towards 2030. Governments might still have some leeway to adjust some parts of the fiscal spending not considered as low-carbon (highcarbon, unclear, supporting the status quo), for example by repurposing committed funding to lowcarbon activities. Some countries assessed in this study show that such realigned spending can be done. However, they would need to do so in a timely manner.

Another important implication of this study's findings is that two-thirds of the total low-carbon spending was identified to be of enabling and catalytic nature. This implies that the emission impact of these expenditures would only unfold over a longer time horizon given. While global $\mathrm{CO}_{2}$ emissions already seem to have almost fully rebounded to pre-crisis levels of 2019 after experience the largest annual percentage decline since World War II (IEA, 2021a, 2021b), it remains to be seen whether and to what extent these expenditures would have impact on emissions toward 2030 and beyond.

While governments' spending decisions in the context of the COVID-19 economic recovery consider many important national and socio-economic circumstances facing a global health and economic crisis, their collective actions remain inadequate considering both the scientific evidence on the urgency to fight climate change and governments' own long-term climate commitments.

\subsection{Limitations of the analysis}

The analysis for key emitters faces several methodological limitations. The first relates to the data cutoff date; the analysis considers all fiscal rescue and recovery announcements for the key emitters as of May 2021. For this reason, the present analysis only represents a snapshot in time for all key emitters assessed. Moreover, some of the reported response measures included in our analysis are still pending approval: the tracking of fiscal spending of EU Member States by May 2021 builds on draft versions of their Recovery \& Resilience Plans pending further adjustments final approval by national governments and the Council of the European Union as of May 2021. At the same time, national governments' fiscal measures may become less driven by the responses to the pandemic as the world gradually shifts toward a post-COVID 'new normal'. In this regard, we argue the findings of this study are representative of countries' fiscal measures, both implemented and planned or under discussion, primarily driven by the pandemic. Data for the EU Member States comes exclusively from the Green Recovery Tracker (E3G \& Wuppertal Institut, 2021). This tracker is limited to recovery measures only and exclusively covers EU member states. This difference in scope limits the comparability of results between the $16 \mathrm{EU}$ Member States and the other key emitters covered in this study. As of May 2021, the Green Recovery Tracker only provides data for 16 EU Member States, not all 27 EU Member States.

Second, there was limited or no information on the timeframe of announced investments and the total committed amount for several rescue and recovery measures. For example, only a unitary subsidy value is provided for some measures providing subsidies for activities such as the purchase of electric vehicles, but no estimate of the program's total budgetary scope. Furthermore, many measures were announced as part of larger rescue and recovery packages, where a disaggregation of the announced expenditures committed per individual measure was not available. Following the approach by Callaghan et al. (2021), we have assumed an even split between measures in some of these cases. Still, we do not have information on the amount committed for 518 measures (18\% of measures collected in the database for key emitters analysed). While this uncertainty would not affect the overall findings of our analysis due 
to a relatively small share of total fiscal spending, any interpretation of our country-level results should consider this limitation.

Third, we experience a lack of granularity in applying measure archetypes to diverse range of rescue and recovery measures with country-specific contexts. Policy options available to governments across the world are similar enough that the application of standardised policy archetypes to categorise public spending allows for a meaningful comparison across countries. However, using such an archetype to code the level of greenness and the emissions impact type of policies across countries may potentially ignore country-specific contexts. For example, the GHG emission impact of electric vehicle investments can be substantially affected by the electricity mix of the country where these investments are rolled out. In other cases, case-by-case judgements had to be made to assign a level of greenness to a rescue and recovery measure archetype: For example, measures catalogued as "other building upgrade support" included green components such as support for "eco-friendly facilities and schools", while in other cases measures under the same archetype included traditional building upgrades or maintenance investments. In total, we have manually recoded around 100 measures to account for measure-specific information.

Fourth, we encounter limits to the extent we can harmonise the three different datasets with substantial differences in scopes. The basis for our analysis is the Global Recovery Observatory database (O'Callaghan, Yau, Murdock, Tritsch, Janz, Blackwood, Purroy Sanchez, L., Sadler, et al., 2021), which includes both rescue and recovery measures focusing on fiscal spending. This data is used for every country covered except the 16 EU Member States. For six key emitters analysed, we fill identified data gaps in the Global Recovery Observatory database using data from the Energy Policy Tracker (2021). This database exclusively tracks measures that support the energy sector, both fossil and low-carbon energy, and it covers both rescue and recovery measures. While harmonizing data from the Energy Policy Tracker with the Global Recovery Observatory database helps to provide a more complete picture, this process required systematic cross-checking to avoid double-counting.

\section{Conclusions and recommendations}

More than 18 months into the COVID-19 pandemic, global $\mathrm{CO}_{2}$ emissions seem to have almost fully rebounded to pre-crisis levels of 2019 after experiencing the largest annual percentage decline since World War II (IEA, 2021a, 2021b). Despite early announcements by governments to prioritise an inclusive and low-carbon recovery, our analysis of $16 \mathrm{EU}$ Member States and 10 selected key emitters suggests that only parts of governments fiscal stimulus spending indeed has been allocated to low-carbon measures (22\% across all countries assessed). Instead, they dedicate large shares of their rescue and recovery spending to measures supporting the status quo in their economies (35\%) and even provide some fiscal resources to explicitly high-carbon measures (4\%). Our findings also suggest that countries differ substantially in terms of measures considered 'supporting the status quo', going up to $11 \%$ of GDP in the case of South Korea. Governments would have had the chance to implement robust conditions or incentives for a low-carbon transition as part of these measures to further support green recovery.

While low-carbon spending is significant in size across countries (USD 641 billion), almost two-thirds of it is not expected to lead to direct emissions reductions towards 2030. This spending rather supports measures considered enabling (54\% of low-carbon spending) or catalytic (10\%) in nature and might rather unfold its impact over time. These findings suggests that governments have put a distinct emphasis 
on measures triggering transformational change over time within their low-carbon spending, not just exclusively focus on measures generating direct emission reduction impact.

We draw several recommendations for policy makers from our analysis.

First, governments worldwide should enhance their preparedness and capabilities to design and swiftly implement low-carbon rescue and recovery measures in a timely manner after experiences with both the Global Financial Crisis in 2009/2010 and the outbreak of the COVID-19 pandemic in 2020. For example, policy makers can put regulatory frameworks in place to define key considerations for lowcarbon transition for any corporate liquidity support disbursed in times of crisis.

Second, this also points to the overall importance of well-developed project pipelines in line with both national mid- and long-term targets and the Paris Agreement objectives. This way governments enhanced their flexibility to identify appropriate measures in a timely manner once economic and social crises arise.

Third and last, the identification of key lessons learnt in the policy response to the COVID-19 pandemic remains important to inform streamlining of low-carbon budgeting into upcoming annual fiscal budgeting cycles and investment projects. While fiscal spending in response to the pandemic has been unprecedented at scale, reaching around USD 11.1 trillion in fiscal rescue and recovery spending as of May 2021 for the countries assessed in this study, upcoming fiscal budgeting cycles will matter even more so given tight limited resources after months into the pandemic.

\section{Acknowledgements}

The authors thank Miles Perry (DG CLIMA, European Commission), Michel den Elzen, Ioannis Dafnomilis, and Hsing-Hsuan Chen (PBL Netherlands Environmental Assessment Agency) for the valuable comments. We also thank Brian O'Callaghan (Global Recovery Observatory), Helena Mölter (Green Recovery Tracker), their teams, and the Energy Policy Tracker for the generous provision of their tracker's underlying datasets.

This work is supported by European Union's Horizon 2020 Research and Innovation Programme under grant agreement No. 821471 (ENGAGE). 


\section{References}

Aghion, P., Hepburn, C., Teytelboym, A., \& Zenghelis, D. (2014). Path dependence, innovation and the economics of climate change Policy paper. http://www.lse.ac.uk/grantham/

Buckle, S., Ellis, J., Aguilar Jaber, A., Rocha, M., Anderson, B., \& Bjersér, P. (2020). Addressing the COVID-19 and climate crises: Potential economic recovery pathways and their implications for climate change mitigation, NDCs and broader socio-economic goals. www.oecd.org/environment/cc/ccxg.htm

Climate Action Tracker. (2020). Paris Agreement turning point: Wave of net zero targets reduces warming estimate to $2.1^{\circ} \mathrm{C}$ in 2100 - All eyes on 2030 targets (Issue December 2020). Climate Action Tracker (CAT). https://climateactiontracker.org/documents/829/CAT_2020-1201_Briefing_GlobalUpdate_Paris5Years_Dec2020.pdf?fbclid=IwAR2e_SHEJes6bml9Y118I_d M1KEqrLTtSyfXxWB3QbPi5e3TCZ7XH0ph2Co

E3G, \& Wuppertal Institut. (2021). Green Recovery Tracker. https://www.greenrecoverytracker.org/

EDGAR. (2019). Fossil CO2 and GHG emissions of all world countries. https://edgar.jrc.ec.europa.eu/overview.php?v=booklet2019\&dst=GHGemi

Energy Policy Tracker. (2021). Energy Policy Tracker. https://www.energypolicytracker.org/about/

Forster, P. M., Forster, H. I., Evans, M. J., Gidden, M. J., Jones, C. D., Keller, C. A., Lamboll, R. D., Quéré, C. Le, Rogelj, J., Rosen, D., Schleussner, C.-F., Richardson, T. B., Smith, C. J., \& Turnock, S. T. (2020). Current and future global climate impacts resulting from COVID-19. Nature Climate Change. https://doi.org/10.1038/s41558-020-0883-0

Green Recovery Tracker. (2021). Is the EU Recovery and Resilience Facility Enabling a Green Recovery? Summary of findings from the Green Recovery Tracker. Green Recovery Tracker (Wuppertal Institut, E3G).

Hepburn, C., O'Callaghan, B., Stern, N., Stiglitz, J., \& Zenghelis, D. (2020). Will COVID-19 fiscal recovery packages accelerate or retard progress on climate change? Oxford Review of Economic Policy, 36(S1), 46.

Höhne, N., den Elzen, M., Rogelj, J., Metz, B., Fransen, T., Kuramochi, T., Olhoff, A., Alcamo, J., Winkler, H., Fu, S., Schaeffer, M., Schaeffer, R., Peters, G. P., Maxwell, S., \& Dubash, N. K. (2020). Emissions: world has four times the work or one-third of the time. Nature, 579(March), 25-28. https://www.nature.com/articles/d41586-020-00571-x

Höhne, N., Hans, F., Olhoff, A., Bhatia, P., O'Callaghan, B., Raga, S., \& Yau, N. (2020). Bridging the gap - implications of current COVID-19 fiscal rescue and recovery measures. In Emissions Gap Report 2020. United Nations Environment Programme.

IEA. (2020). Sustainable Recovery. World Energy Outlook Special Report in collaboration with the International Monetary Fund. International Energy Agency. https://www.iea.org/reports/sustainable-recovery

IEA. (2021a). Global Energy Review 2021. International Energy Agency, Paris, France. https://www.iea.org/reports/global-energy-review-2021/co2-emissions

IEA. (2021b). Net Zero by 2050: A Roadmap for the Global Energy Sector. International Energy Agency. https://www.iea.org/reports/net-zero-by-2050

IEA. (2021c). Sustainable Recovery Tracker.

Jotzo, F., Longden, T., \& Anjum, Z. (2020). Fiscal stimulus for low-carbon compatible COVID-19 recovery: criteria for infrastructure investment (No. 2005; CCEP Working Paper). https://www.researchgate.net/profile/Thomas_Longden/publication/342121861_Fiscal_stimulus_ for_low-carbon_compatible_COVID-

19_recovery_criteria_for_infrastructure_investment/links/5ee30e68299bf1faac4e78c8/Fiscalstimulus-for-low-carbon-compatible-COVID-19- 
Krebel, L., Stirling, A., Van Lerven, F., \& Arnold, S. (2020). Building a green stimulus for COVID-19. A recovery plan for a greener, fairer future. www.neweconomics.org

Lahcen, B., Brusselaers, J., Vrancken, K., Dams, Y., Da Silva Paes, C., Eyckmans, J., \& Rousseau, S. (2020). Green Recovery Policies for the COVID-19 Crisis: Modelling the Impact on the Economy and Greenhouse Gas Emissions. Environmental and Resource Economics, 76(4), 731-750. https://doi.org/10.1007/s10640-020-00454-9

Meles, T. H., Ryan, L., \& Wheatley, J. (2020). COVID-19 and EU Climate Targets: Can We Now Go Further? Environmental and Resource Economics, 76(4), 779-787. https://doi.org/10.1007/s10640-020-00476-3

O'Callaghan, B. (2021). Global Recovery Observatory: Draft Methodology Document. https://recovery.smithschool.ox.ac.uk/wp-content/uploads/2021/03/20210201-Global-RecoveryObservatory-Draft-Methodology-Document-.pdf

O’Callaghan, B., \& Murdock, E. (2021). Are We Building Back Better? Evidence from 2020 and Pathways for Inclusive Green Recovery Spending. https://wedocs.unep.org/bitstream/handle/20.500.11822/35281/AWBBB.pdf

O'Callaghan, B., Yau, N., Murdock, E., Tritsch, D., Janz, A., Blackwood, A., Purroy Sanchez, L., Sadler, A., Wen, E., Kope, H., Flodell, H., Tillman-Morris, L., Ostrovsky, N., Kitsberg, A., Lee, T., Hristov, D., Didarali, Z., Chowdhry, K., Karlubik, M., Shewry, A., Bialek, F., ... Hepburn, C. (2021). Global Recovery Observatory Database May 2021 Update. Oxford University Economic Recovery Project. https://recovery.smithschool.ox.ac.uk/wp-content/uploads/2021/03/20210310Global-Recovery-Observatory-_-publicv3.xlsx

O’Callaghan, B., Yau, N., Murdock, E., Tritsch, D., Janz, A., Blackwood, A., Purroy Sanchez, L. Sadler, A., Wen, E., Kope, H., Flodell, H., Tillman-Morris, L. Ostrovsky, N. Kitsberg, A., Lee, T., Hristov, D., Didarali, Z. Chowdhry, K. Karlubik, M., Shewry, A., Bialek, F., Wang, M. Rosenbaum, N. Gupta, S., Hazell, T., Angell, Z., \& Hepburn, C. (2021). Global Recovery Observatory - Webpage summary analysis per country. Oxford University Economic Recovery Project. https://recovery.smithschool.ox.ac.uk/tracking/

OECD. (2021). The OECD Green Recovery Database: Examining the environmental implications of COVID-19 recovery policies. https://www.oecd.org/coronavirus/policy-responses/the-oecdgreen-recovery-database-47ae0f0d/

Petersberg Climate Dialogue XI. (2020). Co-Chair's Conclusions. BMU. https://www.bmu.de/fileadmin/Daten_BMU/Download_PDF/Klimaschutz/pcd_xi_cochairs_con clusions_bf.pdf

Pollitt, H., Lewney, R., Kiss-Dobronyi, B., \& Lin, X. (2020). A Post-Keynesian approach to modelling the economic effects of Covid-19 and possible recovery plans.

Shan, Y., Ou, J., Wang, D., Zeng, Z., Zhang, S., Guan, D., \& Hubacek, K. (2021). Impacts of COVID19 and fiscal stimuli on global emissions and the Paris Agreement. Nature Climate Change, 11(3), 200-206. https://doi.org/10.1038/s41558-020-00977-5

Strand, J., \& Toman, M. (2010). "Green Stimulus," Economic Recovery, and Long-Term Sustainable Development". The World Bank - Policy Research Working Paper No. 5163, January, 1-30. papers2://publication/uuid/20BBC125-F90E-4A71-AFBF-2C99433059A4

TEG. (2020). Taxonomy: Final report of the Technical Expert What is the EU Taxonomy? (Issue March). EU Technical Expert Group on Sustainable Finance. https://ec.europa.eu/info/sites/info/files/business_economy_euro/banking_and_finance/document s/200309-sustainable-finance-teg-final-report-taxonomy_en.pdf [accessed on 28 August 2020]

UNEP. (2020). Emissions Gap Report 2020. United Nations Environment Programme. https://www.unep.org/resources/emissions-gap-report-2019

UNFCCC. (2015). Adoption of the Paris Agreement. FCCC/CP/2015/L.9/Rev.1. United Nations 
Framework Conventions on Change.

http://unfccc.int/resource/docs/2015/cop21/eng/109r01.pdf

Vivid Economics. (2021). Green Stimulus Index. Update February 2021. Vivid Economics. https://www.vivideconomics.com/wp-content/uploads/2020/07/GreenStimulusIndex14July.pdf 


\section{Appendix}

Table 2: Selected examples of rescue and recovery measures under different impact type categories ('lowcarbon direct', 'low-carbon enabling', 'low-carbon catalytic', 'high-carbon direct', and 'high-carbon enabling').

\begin{tabular}{|c|c|c|}
\hline Measure & $\begin{array}{l}\text { Type } \\
\text { (level of greenness and } \\
\text { emissions impact type) }\end{array}$ & Explanation \\
\hline $\begin{array}{l}\text { GBR-OXF-016: Net } \\
\text { Zero Innovation } \\
\text { Portfolio }\end{array}$ & $\begin{array}{l}\text { Low-carbon } \\
\text { catalytic }\end{array}$ & $\begin{array}{l}\text { - GBP } 200 \text { million to stimulate private sector investment into near-to-market low-carbon } \\
\text { energy innovations, including Direct Air Capture and green hydrogen. } \\
\text { - Explanation of coding decision for this study: Investment in relatively mature new } \\
\text { technologies, focusing on cost-efficiency improvement for market competitivity could } \\
\text { potentially have moderate/big payoff in mid-term. }\end{array}$ \\
\hline $\begin{array}{l}\text { KOR-OXF-107: } \\
\text { Green Innovation }\end{array}$ & $\begin{array}{l}\text { Low-carbon } \\
\text { catalytic }\end{array}$ & $\begin{array}{l}\text { - USD } 2.35 \text { billion for R\&D in green technologies focusing on long-term support schemes for } \\
\text { technology development. Part of a series of measures supporting green innovation in the } \\
\text { industry sector. } \\
\text { - Explanation of coding decision for this study: Long-term support for new green } \\
\text { technologies can catalyse growth of the sector in the mid to long term. }\end{array}$ \\
\hline $\begin{array}{l}\text { CHN-OXF-032: } \\
\text { Green Vehicle } \\
\text { Investment }\end{array}$ & $\begin{array}{l}\text { Low-carbon } \\
\text { enabling }\end{array}$ & $\begin{array}{l}\text { - Investments in electric vehicle battery charging/swapping facilities, and battery recycling } \\
\text { infrastructure as part of the CNY } 2.8 \text { trillion } 2021 \text { Government Work Report. Aims to } \\
\text { contribute to develop the necessary charging infrastructure for the expansion of low-carbon } \\
\text { transport. } \\
\text { - Explanation of coding decision for this study: Development of necessary infrastructure for } \\
\text { competitive green technologies can boost its expansion in the mid-term. }\end{array}$ \\
\hline $\begin{array}{l}\text { BRA-EPT-035: } \\
\text { BNDES financing of } \\
\text { wind generator } \\
\text { blades }\end{array}$ & $\begin{array}{l}\text { Low-carbon } \\
\text { enabling }\end{array}$ & $\begin{array}{l}\text { - USD } 10 \text { million for national manufacturer of wind generator blades. } \\
\text { - Explanation of coding decision for this study: Measure aiming at boost national wind } \\
\text { industry and enable a quicker roll-out of wind power in the medium-term, provides necessary } \\
\text { supporting infrastructure for already competitive technologies. }\end{array}$ \\
\hline $\begin{array}{l}\text { IND-OXF-054: } \\
\text { Support to coal } \\
\text { mining sector }\end{array}$ & $\begin{array}{l}\text { High-carbon } \\
\text { enabling }\end{array}$ & $\begin{array}{l}\text { - USD } 6.8 \text { billion to develop coal transportation infrastructure as part of a plan to expand } \\
\text { domestic production and replace imports. } \\
\text { - Explanation of coding decision for this study: Measure enables higher domestic coal } \\
\text { production and might support further lock-in of coal power infrastructure. }\end{array}$ \\
\hline $\begin{array}{l}\text { SAU-EPT-001: } \\
\text { Hawiyah Unayzah } \\
\text { underground gas } \\
\text { storage site }\end{array}$ & $\begin{array}{l}\text { High-carbon } \\
\text { enabling }\end{array}$ & $\begin{array}{l}\text { - USD } 1.85 \text { billion on underground gas storage facility. } \\
\text { - Explanation of coding decision for this study: Measure supports the expansion of fossil gas } \\
\text { production and further locks in fossil fuel power infrastructure. }\end{array}$ \\
\hline $\begin{array}{l}\text { GBR-OXF-101: new } \\
\text { road projects }\end{array}$ & $\begin{array}{l}\text { 'Supporting the } \\
\text { status quo' } \\
\text { enabling }\end{array}$ & $\begin{array}{l}\text { - USD } 35 \text { billion to be spent until } 2025 \text { on developing road infrastructure } \\
\text { transport infrastructure without specific consideration of a low-carbon transition and aligned } \\
\text { plans to reduce emissions from the transport sector, enabling an increase in future transport } \\
\text { activity. }\end{array}$ \\
\hline $\begin{array}{l}\text { JPN-EPT-008: } \\
\text { project to advance } \\
\text { RE and EVs } \\
\text { simultaneously }\end{array}$ & Low-carbon direct & $\begin{array}{l}\text { - USD } 80 \text { million for short-term and intensive support for the deployment of EVs, fuel cell } \\
\text { vehicles along with the spread of RE, promoting a zero-carbon lifestyle. } \\
\text { - Explanation of coding decision for this study: Measure supports am increase in RE power } \\
\text { generation and switch to ULEVs which directly impact emissions from electricity and } \\
\text { transport. }\end{array}$ \\
\hline $\begin{array}{l}\text { ZAF-EPT-016: } \\
\text { procurement of new } \\
\text { generation capacity } \\
\text { from gas, diesel, coal } \\
\text { and storage }\end{array}$ & $\begin{array}{l}\text { High-carbon } \\
\text { direct }\end{array}$ & $\begin{array}{l}\text { - National plans for new generation capacity through 513MW from storage (for the year 2022), } \\
3 \text { 000MW from gas. (for the years } 2024 \text { to 2027) and } 1 \text { 500MW from coal (2023 to 2027) } \\
\text { - Explanation of coding decision for this study: Support for new fossil fuel power generation } \\
\text { contributes to direct GHG emission increases. }\end{array}$ \\
\hline $\begin{array}{l}\text { BRA-OXF-014: } \\
\text { Unconditional airline } \\
\text { support }\end{array}$ & $\begin{array}{l}\text { 'Supporting the } \\
\text { status quo' direct }\end{array}$ & $\begin{array}{l}\text { - USD } 650 \text { million rescue package for major Brazilian airlines negotiated with BNDES without } \\
\text { any green conditions } \\
\text { - Explanation of coding decision for this study: Measure considered 'supporting the status } \\
\text { quo' given no specific conditions for a low-carbon transition of supported airlines required, } \\
\text { while airlines will continue their activity straight away (direct). }\end{array}$ \\
\hline
\end{tabular}


Figures

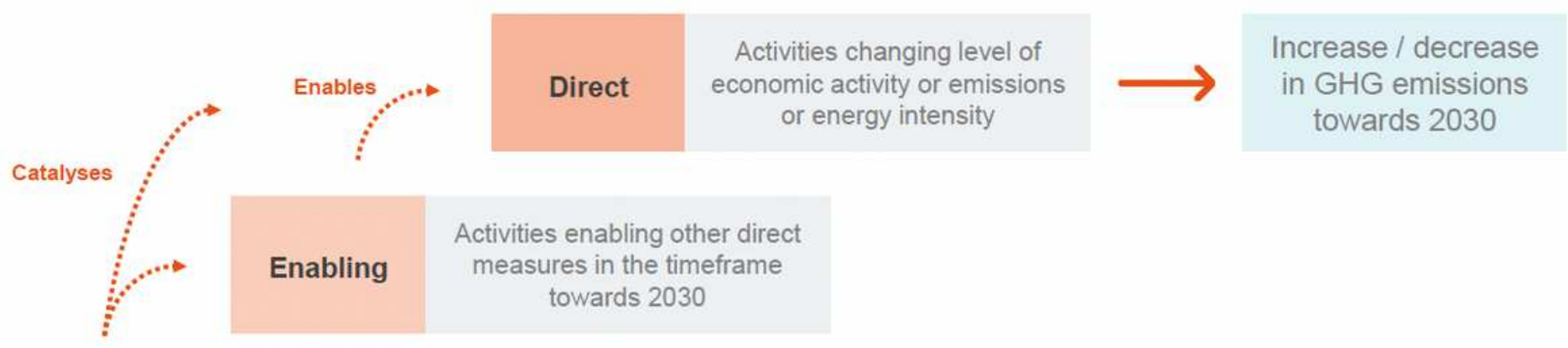

Activities with potential to
Catalytic $\quad \begin{gathered}\text { catalyse enabling or direct } \\ \text { measures }\end{gathered}$

\section{Figure 1}

Conceptual differentiation between direct, enabling, and catalytic measures. Source: authors. 


\section{Emission impact type}

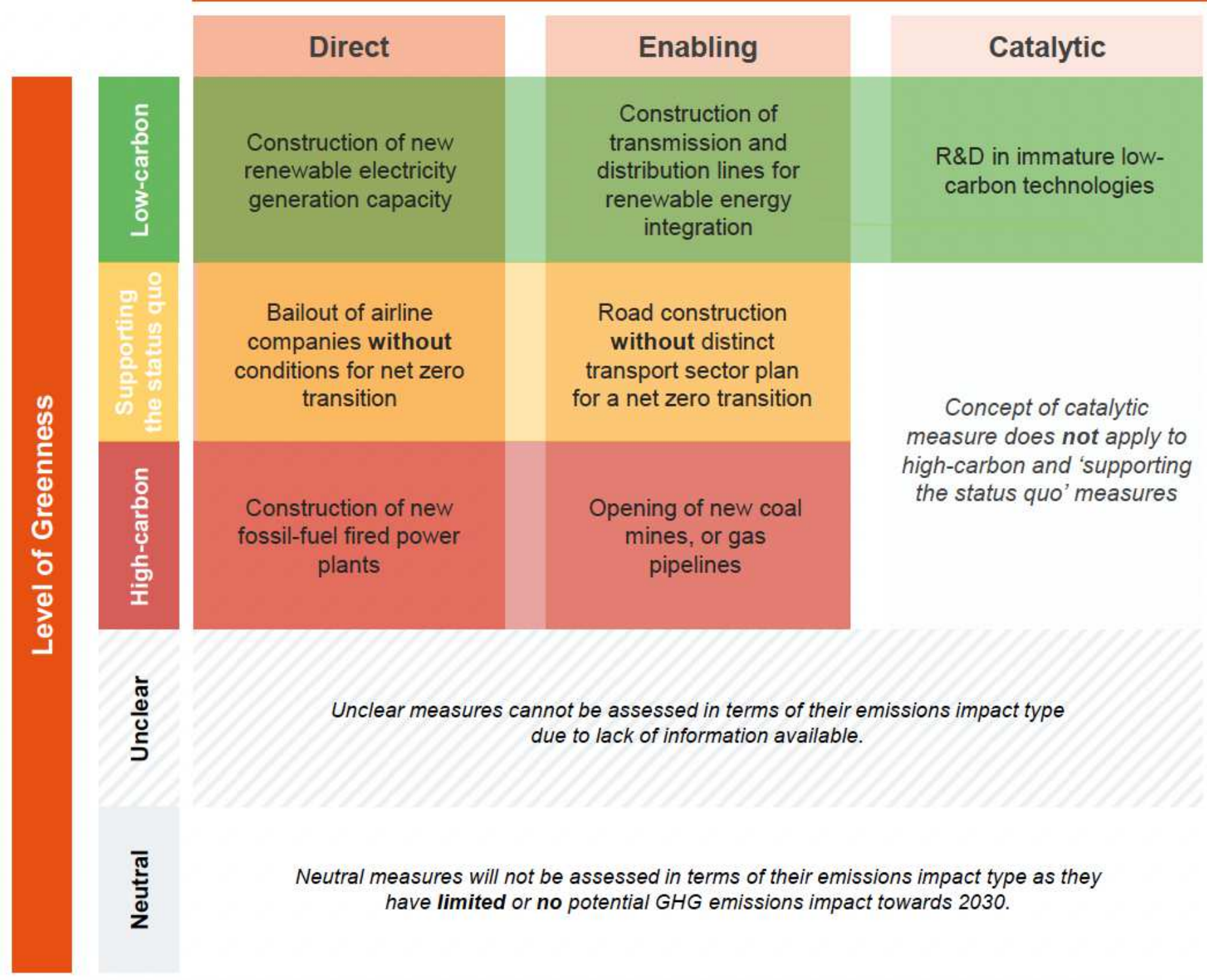

\section{Figure 2}

Framework to assess fiscal rescue and recovery measures according to their emissions impact type greenhouse gas emissions (GHG) towards 2030 (direct, enabling, catalytic) and their level of greenness (low-carbon, supporting status quo, high-carbon, unclear, neutral).

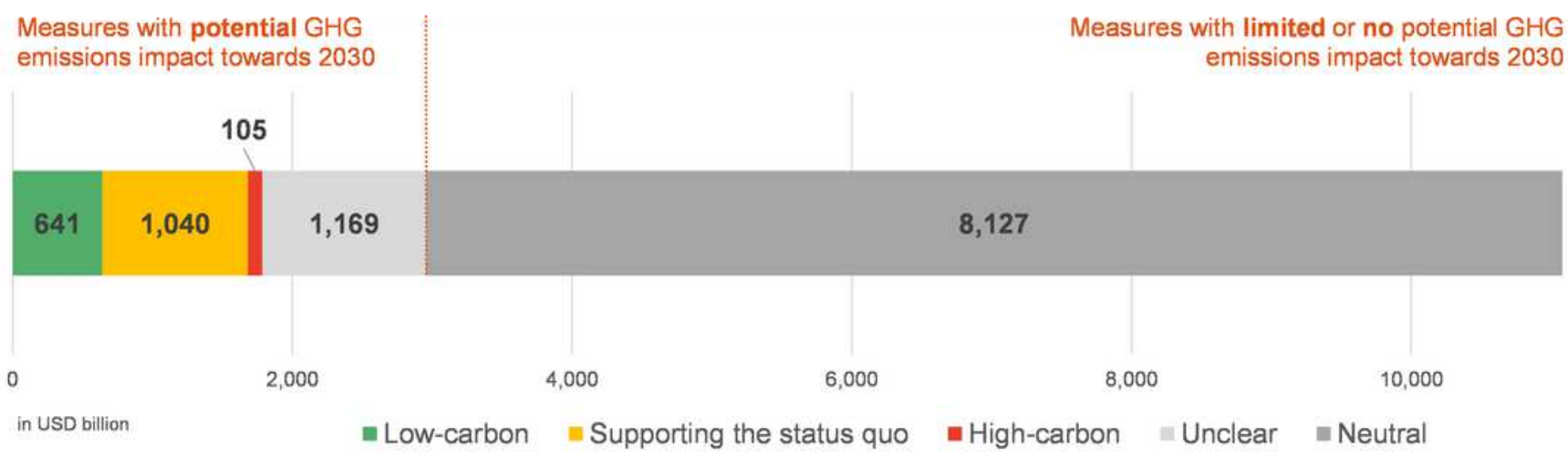




\section{Figure 3}

Overview of aggregated fiscal rescue and recovery spending for 10 key emitting countries and 16 Member States of the European Union assessed in the present analysis as of May 2021. Source: Data from Global Recovery Observatory (2021) and Energy Policy Tracker (2021) for ten key emitters and Green Recovery Tracker (2021) for 16 EU Member States with authors' own coding of all individual measures inspired by measure archetype of the Global Recovery Observatory (O'Callaghan, 2021).

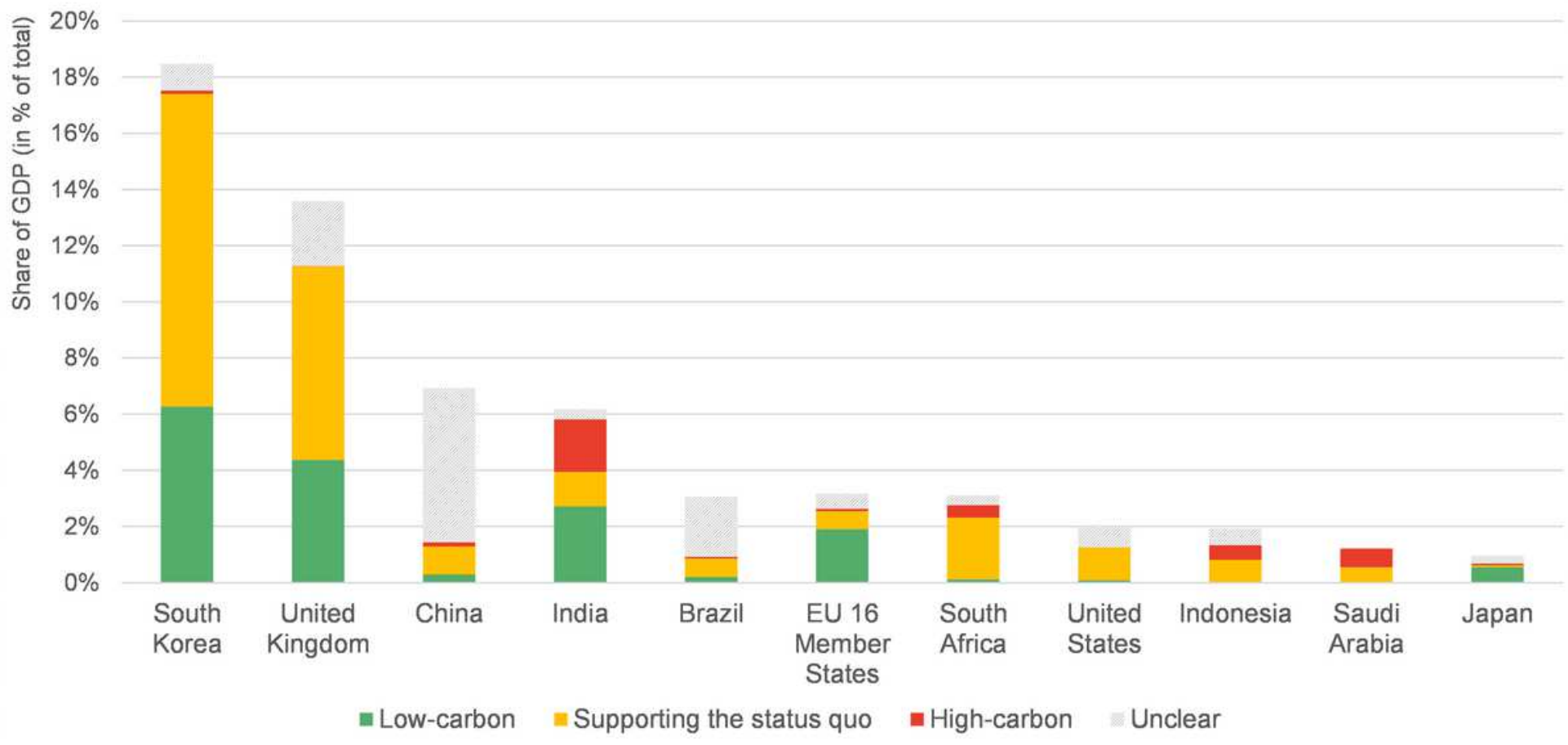

\section{Figure 4}

Fiscal rescue and recovery spending as of May 2021 with potential greenhouse gas (GHG) emissions impact per key emitter as a share of GDP. 

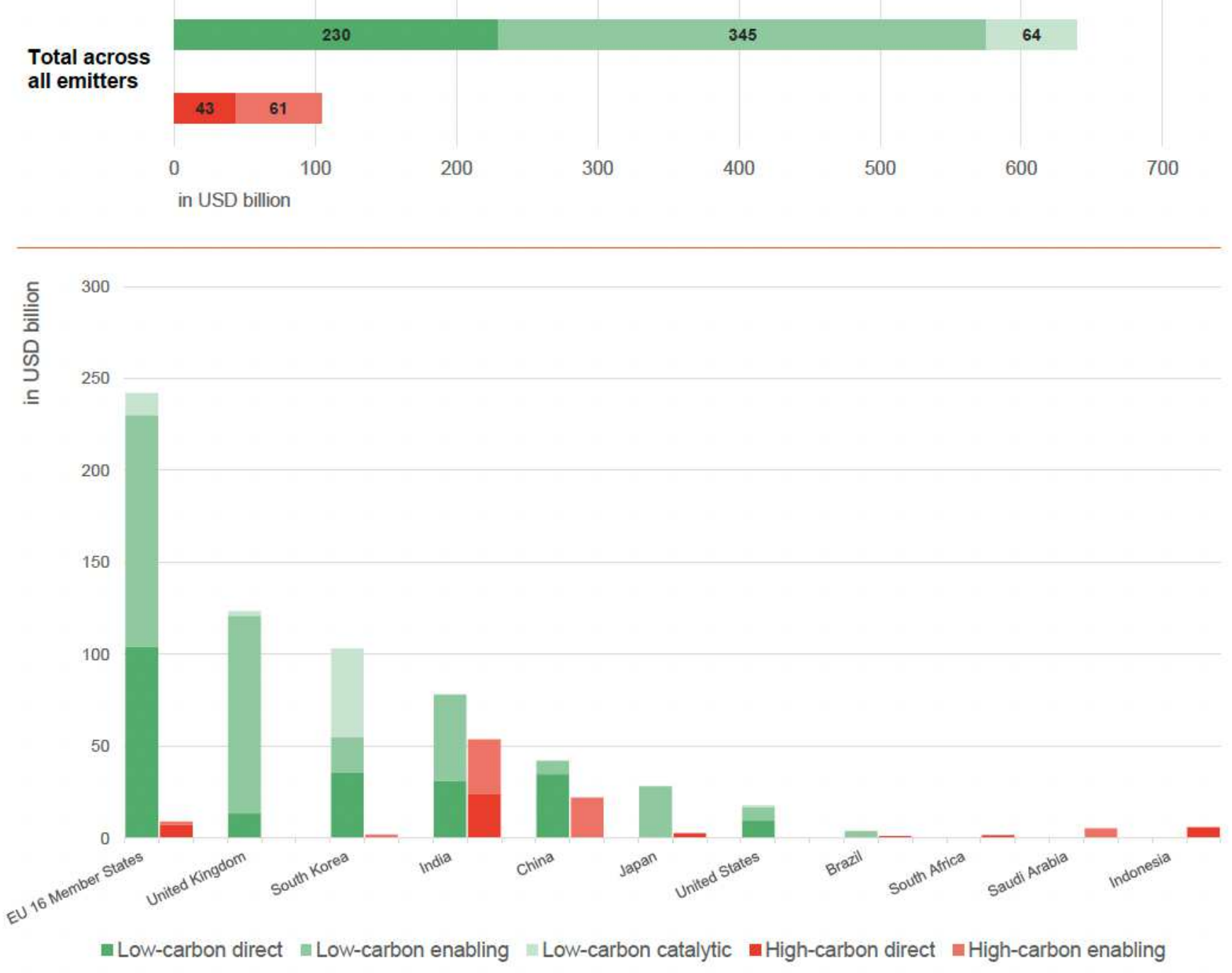

Figure 5

Low-carbon and high-carbon fiscal rescue and recovery spending per key emitter as of May 2021 differentiated by emissions impact type in USD billion.

\section{Supplementary Files}

This is a list of supplementary files associated with this preprint. Click to download.

- GreenRecoveryUnpackingGHGImplicationsSOM.pdf 